\title{
EFFECT OF PROBIOTICS AND THYME ESSENTIAL OIL ON THE ESSENTIAL AMINO ACID CONTENT OF THE BROILER CHICKEN MEAT*
}

\author{
Ebrahim Alfaig ${ }^{1,2 \bowtie}$, Maria Angelovičova ${ }^{1},{\text { Martin } \mathrm{Kral}^{1} \text {, Ondrej Bučko }}^{3}$ \\ ${ }^{1}$ Department of Food Hygiene and Safety, Slovak University of Agriculture in Nitra, Slovak Republic \\ 2Department of Food Science and Technology, Sudan University of Science and Technology, Khartoum, Sudan \\ ${ }^{3}$ Department of Animal Husbandry, Slovak University of Agriculture in Nitra, Slovak Republic
}

\begin{abstract}
Background. Differences in the types and percentages of essential amino acids (EAAs) in food could influence the value of protein consumed and proteins with a high content of EAAs are the most important components of poultry meat. The use of probiotics for meat and carcass quality improvement has been questioned, while feed supplementation with thyme essential oil (TEO) could be considered as useful natural supplement to be applied in the poultry industry to improve meat quality.

Material and methods. Day-old broilers Ross $308(n=400)$ were randomly divided into four groups based on the feed supplement as follows: control, probiotics $0.05 \%$, TEO $0.05 \%$ and combination of probiotics and TEO, while the fattening period was 42 days. Six birds of both sexes from each group were selected as a sample, slaughtered and then stored $\left(-18^{\circ} \mathrm{C}\right)$ for 6 months till the analysis. The muscular homogeneous sample $(50 \mathrm{~g})$ from the breast and thigh of each sample bird was analysed by the Fourier Transform Infrared Spectroscopy method using the device Nicolet 6700 . The essential amino acids content was determined and the quality indicators include chemical score, amino acid score, EAA index and biological value were calculated. Results. The obtained results show that for all the tested EAAs of the breast and thigh muscles, the content numerically increased gradually and progressively within the groups as the control scored the minimum followed by the probiotics group, then the combination group and finally the TEO group which scored the highest results.

Conclusion. It can be concluded that the TEO promoted the increase of all the EAAs and consequently the quality indicators with significant different compared with the control group and significantly different for some EAAs and quality indicators compared with the probiotics group and the combination group.
\end{abstract}

Key words: thyme oil, amino acids, broilers, Fourier transform infrared (FTIR) spectroscopy, probiotics, Ross 308, EAA index

\section{INTRODUCTION}

The nutritional value of meat is usually assessed on the basis of parameters such as content and composition of proteins, levels of amino acids and content of fat [Straková et al. 2002]. Protein quality is an important aspect of human food intake. Furthermore, differences in the types and percentages of essential amino

*This work was supported by the Scientific Grant Agency under the contract No. VEGA 1/0007/11. 
acids in food could influence the value of protein consumed [Aronal et al. 2012].

The quality of meat in general and hence the poultry meat is an extremely complex notion that can be assessed from different points of view. From the standpoint of consumer interests and the slaughter industry, broilers should have not only high slaughter yields and desirable carcass conformation scores but also good aesthetic, sensory and nutritional characteristics. In that respect, the chemical composition of muscle tissue of major primal cuts is an important element of broiler meat quality [Boskovic et al. 2010]. Sample parameters used to determine protein quality include chemical score, amino acid score, EAA index and biological value [Aronal et al. 2012]. Proteins with a high content of essential amino acids are the most important components of poultry meat [Matušovičová 1986, Straková et al. 2002]. Furthermore, muscles from different parts of the carcass have different chemical composition. It has been found that the chemical composition of breast muscles is different from that of thigh muscles [Straková et al. 2002].

Feed supplementation with thyme essential oil could be considered as useful natural supplement to be applied in the poultry industry to improve meat quality [Luna et al. 2010, Alfaig et al. 2013]. The use of probiotics for meat and carcass quality improvement has been questioned and many unclear results have been shown [Pelicano et al. 2003, Alfaig et al. 2013].

Infrared (IR) spectroscopy is a vibrational spectroscopy technique deals with the infrared part of the electromagnetic spectrum and exploits the principle that molecules have specific discrete energy levels corresponding to frequencies at which they rotate or vibrate [Sun 2009, Carbonaro and Nucara 2010, Badr 2012]. Fourier transform infrared (FT IR) spectroscopy is promising analytical techniques to be used. It is fast, not destructive and not involving laborious sample preparation [Kurniawati et al. 2014]. Fourier transform infrared spectroscopy is an excellent analysis tool, as it has already been shown to be a means of rapid determination of important quality parameters [Sherazi et al. 2009]. It is a powerful instrumental tool for both qualitative and quantitative analysis of food components owing to the substantial functional group information contained within the IR spectrum [Amamcharla et al. 2010, Badr 2012].
The aim of this research was to determine the effect of the thyme essential oil and the probiotics as feed additives on the meat quality and in this paper the results are highlighting the essential amino acids of the broiler chicken breast and thigh meat.

\section{MATERIAL AND METHODS}

The experiment was carried out at the Poultry Farm Ltd., Zámostie, Slovakia, the chicks were reared in pens equipped with a hay deep litter, while the slaughtering and the analysis was done in the laboratories of the Slovak University of Agriculture in Nitra, Slovakia.

Animals and diets. Day-old broilers Ross $308(n=$ 400) were randomly divided into four groups. The first group was control which fed the basal diet, the second group was fed the basal diet with $0.05 \%$ probiotics (Bacillus subtilis PB6, CloSTAT) with the activity minimum $2 \cdot 107 \mathrm{CFU} \cdot \mathrm{g}^{-1}$, the third was thyme group which fed the basal diet with $0.05 \%$ thyme essential oil (Thymus vulgaris L.), and the fourth was a combination group which fed the basal diet with $0.05 \%$ thyme essential oil and $0.05 \%$ probiotics. Three nutritional phases (starter, grower, and finisher) were implemented as in Table 1. The fattening period was 42 days divided into three stages from 1-18 days as a starter, 19-31 days grower and 32-42 days as a finisher. Six birds of both sexes from each group were randomly selected as samples, slaughtered then the carcasses were mechanically defeathered, manually eviscerated, and cut up after reaching an internal carcass temperature of $4^{\circ} \mathrm{C}$. The breasts and thighs of the sample chickens then stored $\left(-18^{\circ} \mathrm{C}\right)$ for 6 months. Before the analysis the frozen meat samples were thawed by cooling in the fridge $\left(4^{\circ} \mathrm{C}\right)$ for overnight then the breast and thigh muscles (without skin) samples were prepared, minced and homogenized.

Amino acid analysis. The amino acid composition of the chicken meat samples was measured according to Bučko et al. [2012] by FT IR spectroscopy. The muscular without skin homogeneous sample $(50 \mathrm{~g})$ was analysed by the FT IR method using the device Nicolet 6700 . The infrared spectrum of the muscular homogeneous analysis itself was carried out by the molecular spectroscopy method. The principle of this method is the absorption of the infrared spectrum 
Table 1. Ingredient of the basal diet, \%

\begin{tabular}{lccc}
\hline \multicolumn{1}{c}{ Component } & Starter & Grower & Finisher \\
\hline Wheat & 35.00 & 36.00 & 30.00 \\
Maize & 35.00 & 40.00 & 45.00 \\
Soybean meal & 21.00 & 17.00 & 17.00 \\
Fish meal 71\% & 4.00 & 3.00 & 2.50 \\
Dry blood meal & 1.25 & 1.25 & 1.25 \\
Lime stone & 1.05 & 1.00 & 1.13 \\
Monocalcium phosphate & 0.90 & 0.60 & 0.90 \\
P 22.7\% & & & \\
Salts & 0.10 & 0.15 & 0.20 \\
Sodium biocarbonate & 0.15 & 0.15 & 0.22 \\
Lysine HCL & 0.10 & 0.08 & 0.30 \\
Methionine & 0.15 & 0.22 & 0.30 \\
Bergafat & 0.58 & - & - \\
Clinacox 0.5\% ${ }^{*}$ & 0.02 & - & - \\
SACOX 12\% ${ }^{* *}$ & - & 0.05 & - \\
EUROMIX BR 0.5\% & 0.50 & 0.50 & 0.50 \\
\hline
\end{tabular}

${ }^{*}$ Clinacox $0.5 \%$ active ingredient: each kg contains 5 grams of diclazuril. As an aid in the prevention of coccidiosis caused by Eimeria acervulina, E. brunetti, E. maxima, E. mitis, E. necatrix and E. tenella in broiler chickens.

${ }^{* *}$ SACOX is $12 \%$ micro granulated salinomycin sodium besides strong control of coccidiosis. The approved dose range is 50 to $70 \mathrm{mg} / \mathrm{kg}$ complete feed in the EU.

${ }^{* * *}$ EUROMIX BR $0.5 \%$ the active substances per kilogram of premix: vitamin A $2500000 \mathrm{IU}$, vitamin E $20000 \mathrm{mg}$, vitamin $\mathrm{D}_{3}$ $800000 \mathrm{IU}$, niacin $12000 \mathrm{mg}$, d-pantothenic acid $3000 \mathrm{mg}$, riboflavin $1800 \mathrm{mg}$, pyridoxine $1200 \mathrm{mg}$, thiamine $600 \mathrm{mg}$, menadione $800 \mathrm{mg}$, ascorbic acid $20000 \mathrm{mg}$, folic acid $400 \mathrm{mg}$, biotin $40 \mathrm{mg}$, kobalamin $8.0 \mathrm{mg}$, choline $100000 \mathrm{mg}$, betaine $50000 \mathrm{mg}$, Mn $20000 \mathrm{mg}$, Zn $16000 \mathrm{mg}$, Fe $14000 \mathrm{mg}, \mathrm{Cu}$ $2400 \mathrm{mg}$, Co $80 \mathrm{mg}$, I $200 \mathrm{mg}$, Se $50 \mathrm{mg}$.

during the sample transition where there is a change of the rotary vibrating energetic conditions of the molecule depending on the changes of the dipole momentum molecule. The analytical output is the infrared spectrum which is a graphic representation of the functional dependence of the energy, mostly given in transmittance percentage $(T)$ or absorbance units $(A)$ on the wavelength of the incident emission.
The transmittance is defined as a ratio of the intensity of the emission which has passed the sample (I) and the intensity of the emission emitted by the source $\left(I_{o}\right)$. The absorbance is defined as a decimal logarithm $I / T$. The dependence of the energy on the wavelength is logarithmic, so a repetency - defined as a reciprocal of the wavelength - is used therefore the presented dependence of the energy on the repetency is a linear function.

Chemical score, amino acid score, EAA index and biological value. The chemical score $\left(C_{S}\right)$ was calculated for each amino acid according to the following formula: $C_{S}=A_{x} / A_{s}$, where in $A_{x}$ is the content of an amino acid in the investigated protein (\%) and $A_{s}$ is the content of an amino acid in the standard protein. Whole egg protien was used as standard as reported by Block and Mitchell [1946] (Table 3). The Essential Amino Acid Index (EAAI) is a geometrical average of $C_{S}$ values [Písaříková et al. 2005, Straková et al. 2009]. The biological value of the experimental food materials was calculated from EAAI using Oser's [1959] method as:

$$
\text { Biological value }\left(B_{V}\right)=1.09(\text { EAAI })-11.7
$$

The amino acid score was determined by comparing the essential amino acid contents of the samples to the amino acid contents suggested for humans [Sawar and McDonough 1990, Straková et al. 2009]. The amino acid content recommended for children aged 2-5 years is used to calculate amino acid score of the samples [FAO/WHO/UNU 1985, Straková et al. 2009] (Table 3).

\section{STATISTICAL ANALYSIS}

Data were analysed using R i386 2.15.2 for Windows statistical program for the ANOVA test, while Tukey's HSD (honestly significant difference) multiple comparison test conducted to find means that are significantly different from each other.

\section{RESULTS AND DISCUSSION}

Essential amino acid composition of the chicken breast. The essential amino acid composition of the chicken breast meat of the four experimental groups was shown in Table 2. For the all tested 
Alfaig E., Angelovičova M., Kral M., Bučko O., 2014. Effect of probiotics and thyme essential oil on the essential amino acid content of the broiler chicken meat. Acta Sci. Pol., Technol. Aliment. 13(4), 425-432.

Table 2. Amino acid composition of chicken breast muscles, g/100 g dry muscle

\begin{tabular}{|c|c|c|c|c|c|c|c|}
\hline \multirow[b]{2}{*}{ Amino acids } & \multicolumn{4}{|c|}{ The experimental groups } & \multirow{2}{*}{$\begin{array}{l}\text { Staraková et al. } \\
{[2002]^{*}}\end{array}$} & \multirow{2}{*}{$\begin{array}{l}\text { Wattanachant } \\
\text { et al. [2004] }]^{* *}\end{array}$} & \multirow{2}{*}{$\begin{array}{c}\text { Aronal et al. } \\
{[2012]} \\
\text { Hamm }[1981]^{* * *}\end{array}$} \\
\hline & control & probiotics & thyme & $\begin{array}{l}\text { probiotics+ } \\
\text { thyme }\end{array}$ & & & \\
\hline Arginine & $6.21 \pm 0.60^{\mathrm{b}}$ & $6.64 \pm 0.27^{\mathrm{ab}}$ & $7.08 \pm 0.36^{\mathrm{a}}$ & $6.62 \pm 0.43^{\mathrm{ab}}$ & 6.548 & 4.39 & 6.54 \\
\hline Cysteine & $1.38 \pm 0.10^{\mathrm{b}}$ & $1.44 \pm 0.04^{\mathrm{b}}$ & $1.56 \pm 0.08^{\mathrm{a}}$ & $1.46 \pm 0.08^{\mathrm{ab}}$ & - & 0.31 & 0.70 \\
\hline Phenylalanine & $4.11 \pm 0.38^{\mathrm{b}}$ & $4.36 \pm 0.16^{\mathrm{ab}}$ & $4.61 \pm 0.23^{\mathrm{a}}$ & $4.34 \pm 0.29^{\mathrm{ab}}$ & 1.902 & 3.01 & 4.03 \\
\hline Histidine & $4.43 \pm 0.38^{\mathrm{b}}$ & $4.55 \pm 0.23^{\mathrm{b}}$ & $5.14 \pm .24^{\mathrm{a}}$ & $4.55 \pm 0.22^{\mathrm{b}}$ & 4.656 & 2.90 & 4.28 \\
\hline Isoleucine & $3.64 \pm 0.36^{\mathrm{b}}$ & $3.89 \pm 017^{\mathrm{ab}}$ & $4.25 \pm 0.20^{\mathrm{a}}$ & $3.89 \pm 0.26^{\mathrm{ab}}$ & 4.298 & 2.41 & 4.34 \\
\hline Leucine & $7.90 \pm 0.73^{b}$ & $8.38 \pm 0.31^{\mathrm{ab}}$ & $8.94 \pm 0.42^{\mathrm{a}}$ & $8.38 \pm 0.53^{\mathrm{ab}}$ & 6.785 & 4.29 & 8.25 \\
\hline Lysine & $8.33 \pm 0.80^{\mathrm{b}}$ & $8.89 \pm .37^{\mathrm{ab}}$ & $9.50 \pm 0.48^{\mathrm{a}}$ & $8.87 \pm 0.59^{\mathrm{ab}}$ & 8.030 & 3.41 & 8.31 \\
\hline Methionine & $2.93 \pm 0.24^{\mathrm{b}}$ & $3.08 \pm 0.14^{\mathrm{ab}}$ & $3.34 \pm 0.16^{\mathrm{a}}$ & $3.08 \pm 0.17^{\mathrm{ab}}$ & 2.014 & 1.88 & 3.25 \\
\hline Threonin & $4.23 \pm 0.36^{\mathrm{b}}$ & $4.44 \pm 0.16^{\mathrm{b}}$ & $4.99 \pm 0.16^{\mathrm{a}}$ & $4.50 \pm 0.25^{\mathrm{b}}$ & 3.530 & 3.02 & 4.77 \\
\hline Valin & $4.05 \pm 0.32^{\mathrm{b}}$ & $4.20 \pm 0.16^{\mathrm{b}}$ & $4.63 \pm 0.14^{\mathrm{a}}$ & $4.21 \pm 0.21^{\mathrm{b}}$ & 4.722 & 2.16 & 4.69 \\
\hline
\end{tabular}

For the experimental groups, data are presented as mean \pm standard deviation.

Means within a row lacking a common superscript differ $(p<0.05)$ in the experimental groups.

*Identified as Ross 308 broiler chickens (male, 42 days; g/100 g dry matter).

${ }^{* *}$ Identified as Broiler (commercial breed, CP707) chicken (g/100 g dry matter).

${ }^{* * *}$ Identified as chicken meat ( $\mathrm{g} / 100 \mathrm{~g}$ dry matter).

essential amino acids the control group scored the numerically lowest results while the thyme essential oil group scored the highest. For Arginine, Phenylalanine, Isoleucine, Leucine, Lysine and Methionine there was significantly different $(p<0.05)$ only between TEO group and the control, while for Cystiene there was significantly different $(p<0.05)$ between TEO group and control group and also between TEO group and probiotics group. For Histidine, Threonin and Valin the TEO group was significantly different $(p<0.05)$ from all the other groups. In general the essential amino acid composition of the probiotics group and the combination group (probiotics and thyme) were almost similar and more close to the control group than the TEO group which scored the highest value for all the tested amino acids. The results of the control group were to such extent close to that reported by Hamm [1981] and Aronal et al. [2012] and for some amino acids similar to that reported by Staraková et al. [2002]. Compared with the results reported by Wattanachant et al. [2004] who studied the amino acids of the mixed sex broiler chickens, all the tested groups scored higher results for all amino acids. For Isoleucine the result reported by Hamm [1981] and Aronal et al. [2012] and that of Staraková et al. [2002] were higher even than that obtained by the thyme group. In general for the tested essential amino acids the breast meat appears to have a little bit numerically higher content compared with the same group of the thigh.

Chemical score, amino acid score, EAA index and biological value of breast samples. The calculated nutritional indicators of breast samples are summarized in Table 3. With reference to EAA index, $B_{V}$, the chemical score and amino acid score of all the tested amino acids (except Histidine, Threonin and Valin), there was significantly different $(p<0.05)$ only between TEO group and the control. In respect of the chemical score and amino acid score of Histidine, Threonin and Valin there was a significant difference $(p<0.05)$ between TEO group and all the other groups.

Amino acid composition of the chicken thigh. The essential amino acids results of the chicken thigh 
Alfaig E., Angelovičova M., Kral M., Bučko O., 2014. Effect of probiotics and thyme essential oil on the essential amino acid content of the broiler chicken meat. Acta Sci. Pol., Technol. Aliment. 13(4), 425-432.

Table 3. Calculated nutritional indicators of breast samples

\begin{tabular}{|c|c|c|c|c|c|}
\hline \multirow{2}{*}{ Amino acids } & \multicolumn{4}{|c|}{ The experimental groups } & \multirow{2}{*}{ Standard } \\
\hline & control & probiotics & thyme & probiotics + thyme & \\
\hline \multicolumn{5}{|c|}{ Chemical score of the amino acids, $\%$} & Standard 1 \\
\hline Arginine & $97.06 \pm 9.33^{\mathrm{b}}$ & $103.67 \pm 4.22^{\mathrm{ab}}$ & $110.55 \pm 5.58^{\mathrm{a}}$ & $103.36 \pm 6.79^{\mathrm{ab}}$ & 6.4 \\
\hline Cysteine & $57.36 \pm 4.01^{\mathrm{b}}$ & $60.14 \pm 1.55^{\mathrm{ab}}$ & $64.79 \pm 3.24^{\mathrm{a}}$ & $60.69 \pm 3.28^{\mathrm{ab}}$ & 2.4 \\
\hline Phenylalanine & $65.16 \pm 6.05^{\mathrm{b}}$ & $69.26 \pm 2.53^{\mathrm{ab}}$ & $73.23 \pm 3.58^{\mathrm{a}}$ & $68.94 \pm 4.58^{\mathrm{ab}}$ & 6.3 \\
\hline Histidine & $210.87 \pm 17.9^{b}$ & $216.8 \pm 11.1^{\mathrm{b}}$ & $244.5 \pm 11.6^{\mathrm{a}}$ & $216.4 \pm 10.7^{\mathrm{b}}$ & 2.1 \\
\hline Isoleucine & $45.48 \pm 4.54^{\mathrm{b}}$ & $48.56 \pm 2.12^{\mathrm{ab}}$ & $53.08 \pm 2.45^{\mathrm{a}}$ & $48.67 \pm 3.19^{\mathrm{ab}}$ & 8 \\
\hline Leucine & $85.83 \pm 7.97^{\mathrm{b}}$ & $91.11 \pm 3.41^{\mathrm{ab}}$ & $97.17 \pm 4.60^{\mathrm{a}}$ & $91.07 \pm 5.76^{\mathrm{ab}}$ & 9.2 \\
\hline Lysine & $115.7 \pm 11.16^{\mathrm{b}}$ & $123.5 \pm 5.16^{\mathrm{ab}}$ & $131.9 \pm 6.73^{\mathrm{a}}$ & $123.2 \pm 8.21^{\mathrm{ab}}$ & 7.2 \\
\hline Methionine & $71.54 \pm 5.78^{\mathrm{b}}$ & $75.04 \pm 3.47^{\mathrm{ab}}$ & $81.38 \pm 3.81^{\mathrm{a}}$ & $75.08 \pm 4.22^{\mathrm{ab}}$ & 4.1 \\
\hline Threonin & $86.36 \pm 5.25^{\mathrm{b}}$ & $90.65 \pm 3.27^{b}$ & $101.9 \pm 3.28^{\mathrm{a}}$ & $91.84 \pm 5.08^{\mathrm{b}}$ & 4.9 \\
\hline Valin & $55.50 \pm 4.33^{\mathrm{b}}$ & $57.51 \pm 2.14^{b}$ & $63.38 \pm 1.98^{\mathrm{a}}$ & $57.65 \pm 2.91^{\mathrm{b}}$ & 7.3 \\
\hline \multicolumn{5}{|c|}{ Amino acids score, $\%$} & Standard 2 \\
\hline Cysteine + Methionine & $172.4 \pm 13.2^{\mathrm{b}}$ & $180.8 \pm 7.0^{\mathrm{ab}}$ & $195.7 \pm 7.6^{\mathrm{a}}$ & $181.4 \pm 10.0^{\mathrm{ab}}$ & 2.5 \\
\hline Histidine & $233.1 \pm 19.9^{b}$ & $239.6 \pm 12.3^{b}$ & $270.3 \pm 12.8^{a}$ & $239.2 \pm 11.8^{\mathrm{b}}$ & 1.9 \\
\hline Isoleucine & $129.9 \pm 13.0^{\mathrm{b}}$ & $138.8 \pm 6.0^{\mathrm{ab}}$ & $151.7 \pm 7.0^{\mathrm{a}}$ & $139.0 \pm 9.1^{\mathrm{ab}}$ & 2.8 \\
\hline Leucine & $119.6 \pm 11.1^{\mathrm{b}}$ & $127.0 \pm 4.8^{\mathrm{ab}}$ & $135.5 \pm 6.4^{\mathrm{a}}$ & $126.9 \pm 8.0^{\mathrm{ab}}$ & 6.6 \\
\hline Lysine & $143.6 \pm 13.9^{\mathrm{b}}$ & $153.3 \pm 6.4^{\mathrm{ab}}$ & $163.8 \pm 8.4^{\mathrm{a}}$ & $152.9 \pm 10.2^{\mathrm{ab}}$ & 5.8 \\
\hline Threonin & $124.5 \pm 10.4^{\mathrm{b}}$ & $130.6 \pm 4.7^{\mathrm{b}}$ & $146.9 \pm 4.7^{\mathrm{a}}$ & $132.4 \pm 7.3^{\mathrm{b}}$ & 3.4 \\
\hline Valin & $115.8 \pm 9.0^{\mathrm{b}}$ & $120.0 \pm 4.5^{\mathrm{b}}$ & $132.2 \pm 4.1^{\mathrm{a}}$ & $120.2 \pm 6.1^{\mathrm{b}}$ & 3.5 \\
\hline EAA index, \% & $80.79 \pm 7.03^{b}$ & $85.13 \pm 3.27^{\mathrm{ab}}$ & $92.48 \pm 3.62^{\mathrm{a}}$ & $85.26 \pm 5.01^{\mathrm{ab}}$ & - \\
\hline Biological value & $76.36 \pm 7.66^{\mathrm{b}}$ & $81.09 \pm 3.57^{\mathrm{ab}}$ & $89.11 \pm 3.95^{\mathrm{a}}$ & $81.23 \pm 5.46^{\mathrm{ab}}$ & - \\
\hline
\end{tabular}

Means within a row lacking a common superscript differ $(p<0.05)$ in the experimental groups.

Standard 1: composition of whole egg protein (g of amino acid/16 g nitrogen) as reported by Block and Mitchell [1946].

Standard 2: the amino acid content recommended for children aged 2-5 years as reported by FAO/WHO/UNU [1985].

meat of the four experimental groups are presented in Table 4. For the all tested essential amino acids the control group scored the numerically lowest result while the thyme essential oil group scored the highest. Regarding the Methionine there was significantly different $(p<0.05)$ only between TEO group and the control, while for Arginine, Isoleucine and Lysine there was significantly different $(p<0.05)$ between TEO group and control and also between TEO group and probiotics group. For Cystiene, Histidine, Phenylalanine, Leucine, Threonin and Valin the TEO group was significantly different $(p<0.05)$ from all the other groups.

As shown in Table 4 the thigh essential amino acid composition of the probiotics group and the combination group (probiotics and thyme) were almost similar and more close to the control group than the TEO group. For the control, probiotics and combination 
Alfaig E., Angelovičova M., Kral M., Bučko O., 2014. Effect of probiotics and thyme essential oil on the essential amino acid content of the broiler chicken meat. Acta Sci. Pol., Technol. Aliment. 13(4), 425-432.

Table 4. Amino acid composition of chicken thigh muscles, g/100 g dry muscle

\begin{tabular}{|c|c|c|c|c|c|c|c|}
\hline \multirow[b]{2}{*}{ Amino acids } & \multicolumn{4}{|c|}{ The experimental groups } & \multirow{2}{*}{$\begin{array}{c}\text { Staraková et al. } \\
{[2002]^{*}}\end{array}$} & \multirow{2}{*}{$\begin{array}{l}\text { Wattanachant } \\
\text { et al. }[2004]^{* *}\end{array}$} & \multirow{2}{*}{$\begin{array}{c}\text { Aronal et al. } \\
{[2012]} \\
\text { Hamm }[1981]^{* * *}\end{array}$} \\
\hline & control & probiotics & thyme & $\begin{array}{l}\text { probiotics+ } \\
\text { thyme }\end{array}$ & & & \\
\hline Arginine & $5.49 \pm 0.39^{\mathrm{b}}$ & $5.55 \pm 0.30^{\mathrm{b}}$ & $6.35 \pm 0.54^{\mathrm{a}}$ & $5.64 \pm 0.54^{\mathrm{ab}}$ & 3.933 & 4.75 & 6.89 \\
\hline Cysteine & $1.21 \pm 0.06^{\mathrm{b}}$ & $1.21 \pm 0.04^{\mathrm{b}}$ & $1.43 \pm 0.09^{\mathrm{a}}$ & $1.26 \pm 0.08^{\mathrm{b}}$ & - & 0.3 & 0.76 \\
\hline Phenylalanine & $3.62 \pm 0.24^{b}$ & $3.65 \pm 0.19^{\mathrm{b}}$ & $4.16 \pm 0.33^{\mathrm{a}}$ & $3.70 \pm 0.34^{\mathrm{b}}$ & 2.071 & 2.94 & 4.00 \\
\hline Histidine & $3.92 \pm 0.23^{\mathrm{b}}$ & $4.02 \pm 0.23^{\mathrm{b}}$ & $4.57 \pm 0.31^{\mathrm{a}}$ & $4.01 \pm 0.30^{\mathrm{b}}$ & 2.458 & 2.49 & 3.42 \\
\hline Isoleucine & $3.26 \pm 0.24^{b}$ & $3.32 \pm 0.20^{\mathrm{b}}$ & $3.80 \pm 0.32^{\mathrm{a}}$ & $3.36 \pm 0.33^{\mathrm{ab}}$ & 2.978 & 2.29 & 4.15 \\
\hline Leucine & $7 \pm 0.48^{\mathrm{b}}$ & $7.06 \pm 0.37^{\mathrm{b}}$ & $8.08 \pm 0.64^{\mathrm{a}}$ & $7.19 \pm 0.66^{\mathrm{b}}$ & 5.285 & 4.19 & 7.85 \\
\hline Lysine & $7.33 \pm 0.52^{\mathrm{b}}$ & $7.42 \pm 0.40^{\mathrm{b}}$ & $8.51 \pm 0.73^{\mathrm{a}}$ & $7.53 \pm 0.72^{\mathrm{ab}}$ & 5.804 & 3.16 & 8.15 \\
\hline Methionine & $2.58 \pm 0.17^{\mathrm{b}}$ & $2.65 \pm 0.13^{\mathrm{ab}}$ & $2.96 \pm 0.24^{\mathrm{a}}$ & $2.67 \pm 0.22^{\mathrm{ab}}$ & 1.482 & 1.83 & 3.25 \\
\hline Threonin & $3.76 \pm 0.25^{\mathrm{b}}$ & $3.81 \pm 0.18^{\mathrm{b}}$ & $4.55 \pm 0.33^{\mathrm{a}}$ & $3.92 \pm 0.32^{\mathrm{b}}$ & 2.456 & 2.96 & 5.02 \\
\hline Valin & $3.60 \pm 0.19^{b}$ & $3.66 \pm 0.16^{\mathrm{b}}$ & $4.20 \pm 0.27^{\mathrm{a}}$ & $3.68 \pm 0.23^{b}$ & 3.274 & 2.08 & 3.38 \\
\hline
\end{tabular}

For the experimental groups, data are presented as mean \pm standard deviation.

Means within a row lacking a common superscript differ $(p<0.05)$ in the experimental groups.

*Identified as Ross 308 broiler chickens (male, 42 days; g/100 g dry matter).

${ }^{* *}$ Identified as Broiler (commercial breed, CP707) chicken (g/100 g dry matter).

${ }^{* * *}$ Identified as chicken meat ( $\mathrm{g} / 100 \mathrm{~g}$ dry matter).

groups Arginine, Phenylalanine, Isoleucine, Leucine, Lysine, Methionine and Threonin values were less than that reported by Hamm [1981] and Aronal et al. [2012], while for Cystiene, Histidine and Valin values obtained by the four groups were greater than that reported by Hamm [1981] and Aronal et al. [2012]. The results reported by Staraková et al. [2002] and Wattanachant et al. [2004] for all the tested amino acids were lower than those obtained by the control and experimental groups. Despite of the fact that the control scored the numerical minimum results compared with the other groups for the breast and thigh samples, the statistical analysis showed that there was no significant different between the control and the probiotics group and the combination group and the exception only was in the TEO group.

Chemical score, amino acid score, EAA index and biological value of thigh samples. The calculated nutritional indicators of thigh samples are mentioned in Table 5. Regarding the chemical score of Methionine there was a significant difference $(p<$ 0.05 ) only between TEO group and the control and for Arginine, Isoleucine and Lysine there was a significant difference $(p<0.05)$ between TEO group and control and also between TEO group and probiotics group, while for the rest of the tested amino acids the chemical score samples showed significant difference $(p<0.05)$ between TEO group and the other groups. In connection with EAA index, $B_{V}$ and amino acid score of all the tested amino acids (except Isoleucine and Lysine), there was a significant difference ( $p<$ 0.05 ) between TEO group and the other groups. For the amino acids score of Isoleucine and Lysine there was a significant difference $(p<0.05)$ between TEO group and control and also between TEO group and probiotics group.

\section{CONCLUSION}

Compared to the control group we can conclude that the probiotics numerically increased the amino acid content and the calculated nutritional indicators but without significantly and the same case for the combination group, while the thyme essential oil 
Alfaig E., Angelovičova M., Kral M., Bučko O., 2014. Effect of probiotics and thyme essential oil on the essential amino acid content of the broiler chicken meat. Acta Sci. Pol., Technol. Aliment. 13(4), 425-432.

Table 5. Calculated nutritional indicators of thigh samples

\begin{tabular}{|c|c|c|c|c|}
\hline \multirow{2}{*}{ Amino acids } & \multicolumn{4}{|c|}{ The experimental groups } \\
\hline & control & probiotics & thyme & probiotics + thyme \\
\hline \multicolumn{5}{|c|}{ Chemical score of the amino acids, $\%$} \\
\hline Arginine & $85.76 \pm 6.07^{b}$ & $86.74 \pm 4.70^{\mathrm{b}}$ & $99.14 \pm 8.37^{\mathrm{a}}$ & $88.05 \pm 8.45^{\mathrm{ab}}$ \\
\hline Cysteine & $50.28 \pm 2.70^{\mathrm{b}}$ & $50.35 \pm 1.59^{\mathrm{b}}$ & $59.44 \pm 3.93^{\mathrm{a}}$ & $52.50 \pm 3.44^{\mathrm{b}}$ \\
\hline Phenylalanine & $57.38 \pm 3.85^{\mathrm{b}}$ & $57.88 \pm 3.03^{\mathrm{b}}$ & $66.03 \pm 5.31^{\mathrm{a}}$ & $58.70 \pm 5.32^{\mathrm{b}}$ \\
\hline Histidine & $186.75 \pm 11.06^{\mathrm{b}}$ & $191.59 \pm 10.92^{b}$ & $217.54 \pm 14.55^{\mathrm{a}}$ & $191.11 \pm 14.13^{\mathrm{b}}$ \\
\hline Isoleucine & $40.73 \pm 3.02^{\mathrm{b}}$ & $41.44 \pm 2.45^{\mathrm{b}}$ & $47.46 \pm 4.04^{\mathrm{a}}$ & $41.94 \pm 4.15^{\mathrm{ab}}$ \\
\hline Leucine & $76.09 \pm 5.27^{\mathrm{b}}$ & $76.76 \pm 4.02^{\mathrm{b}}$ & $87.86 \pm 6.95^{\mathrm{a}}$ & $78.10 \pm 7.17^{b}$ \\
\hline Lysine & $101.85 \pm 7.22^{\mathrm{b}}$ & $103.10 \pm 5.52^{b}$ & $118.15 \pm 10.17^{\mathrm{a}}$ & $104.61 \pm 10.00^{\mathrm{ab}}$ \\
\hline Methionine & $63.01 \pm 4.17^{\mathrm{b}}$ & $64.55 \pm 3.16^{\mathrm{ab}}$ & $72.20 \pm 5.81^{\mathrm{a}}$ & $65.12 \pm 5.35^{\mathrm{ab}}$ \\
\hline Threonin & $76.67 \pm 5.07^{\mathrm{b}}$ & $77.72 \pm 3.67^{\mathrm{b}}$ & $92.89 \pm 6.79^{\mathrm{a}}$ & $79.93 \pm 6.47^{\mathrm{b}}$ \\
\hline Valin & $49.25 \pm 2.60^{\mathrm{b}}$ & $50.09 \pm 2.20^{\mathrm{b}}$ & $57.47 \pm 3.76^{\mathrm{a}}$ & $50.37 \pm 3.16^{\mathrm{b}}$ \\
\hline \multicolumn{5}{|c|}{ Amino acids score, $\%$} \\
\hline Cysteine+Methionine & $151.6 \pm 9.4^{\mathrm{b}}$ & $154.2 \pm 6.6^{\mathrm{b}}$ & $175.5 \pm 13.2^{\mathrm{a}}$ & $157.2 \pm 12.1^{\mathrm{b}}$ \\
\hline Histidine & $206.4 \pm 12.2^{\mathrm{b}}$ & $211.8 \pm 12.1^{\mathrm{b}}$ & $240.4 \pm 16.1^{\mathrm{a}}$ & $211.2 \pm 15.6^{b}$ \\
\hline Isoleucine & $116.4 \pm 8.6^{\mathrm{b}}$ & $118.4 \pm 7.0^{\mathrm{b}}$ & $135.6 \pm 11.5^{\mathrm{a}}$ & $119.8 \pm 11.9^{\mathrm{ab}}$ \\
\hline Leucine & $106.1 \pm 7.3^{b}$ & $107.0 \pm 5.6^{\mathrm{b}}$ & $122.5 \pm 9.7^{\mathrm{a}}$ & $108.9 \pm 10.0^{\mathrm{b}}$ \\
\hline Lysine & $126.4 \pm 9.0^{\mathrm{b}}$ & $128.0 \pm 6.9^{b}$ & $146.7 \pm 12.6^{\mathrm{a}}$ & $129.9 \pm 12.4^{\mathrm{ab}}$ \\
\hline Threonin & $110.5 \pm 7.3^{b}$ & $112.0 \pm 5.3^{b}$ & $133.9 \pm 9.8^{\mathrm{a}}$ & $115.2 \pm 9.3^{b}$ \\
\hline Valin & $102.7 \pm 5.4^{\mathrm{b}}$ & $104.5 \pm 4.6^{\mathrm{b}}$ & $119.9 \pm 7.8^{\mathrm{a}}$ & $105.0 \pm 6.6^{\mathrm{b}}$ \\
\hline EAA index, $\%$ & $71.45 \pm 4.62^{\mathrm{b}}$ & $72.46 \pm 3.57^{b}$ & $83.29 \pm 6.36^{\mathrm{a}}$ & $73.58 \pm 6.15^{\mathrm{b}}$ \\
\hline Biological value & $66.18 \pm 5.04^{\mathrm{b}}$ & $67.28 \pm 3.90^{\mathrm{b}}$ & $79.08 \pm 6.93^{\mathrm{a}}$ & $68.51 \pm 6.71^{\mathrm{b}}$ \\
\hline
\end{tabular}

Means within a row lacking a common superscript differ $(p<0.05)$.

promoted the increase of all the essential amino acids and consequently the calculated nutritional indicators with significantly different compared with the control group and significantly for some amino acids compared with the probiotics group and the combination group. These encouraging results can pave the way for increasing the essential amino acids in the meat produced not only from chickens but also from other animals by supplementation of the thyme essential oil in their diet. However, more research is needed to confirm these results.

\section{REFERENCES}

Alfaig E., Angelovičova M., Kral M., Vietoris V., Zidek R., 2013. Effect of probiotics and thyme essential oil on the texture of cooked chicken breast meat. Acta Sci. Pol., Technol. Aliment. 12(4), 379-384.

Amamcharla J.K., Panigrahis S., Logue C.M., Marchello M., Sherwood J.S., 2010. Fourier transform infrared spectroscopy (FTIR) as a tool for discriminating Salmonella typhimurium contaminated beef. Sens. Instr. Food Qual. Safety 4, 1-12. 
Aronal A.P., Huda N., Ahmed R., 2012. Amino acid and fatty acid profiles of peking and muscovy duck meat. Int. J. Poult. Sci. 11, 229-236.

Badr H.M., 2012. Infrared spectroscopy for the detection of irradiated meats. J. Am. Sci. 8, 208-214.

Block R.J., Mitchell H.H., 1946. The correlation of the amino acid composition of proteins with their nutritive value. Nutr. Abst. Rev. 16, 249-278.

Boskovic B.S., Pavlovski Z., Petrović M.D., Dosković V., Rakonjac S., 2010. Broiler meat quality: Proteins and lipids of muscle tissue (Review). Afr. J. Biotechn. 9, 9177-9182.

Bučko O., Lehotayová A., Petrák J., Vavrišínová K., Šimko M., Juráček M., 2012. Effect of organic chromium to carcass composition and chemical composition of adductor muscle in large white breed. Res. Pig Breed. 6, 5-9.

Carbonaro M., Nucara A., 2010. Secondary structure of food proteins by Fourier transform spectroscopy in the mid-infrared region. Amino Acids 38, 679-690.

FAO/WHO/UNU. 1985. Energy and protein requirements. Report of a joint FAO/WHO/UNU Expert Consultation. WHO Tech. Rep. Ser. No. 724, Geneva.

Hamm D., 1981. Amino acid composition of breast and thigh meat from broilers produced in four locations of the United States. J. Food Sci. 46, 1122-1124.

Kurniawati E., Rohman A., Triyana K., 2014. Analysis of lard in meatball broth using Fourier transform infrared spectroscopy and chemometrics. Meat Sci. 96, 94-98.

Luna A., Labaque M.C., Zygadlo J.A., Marin R.H., 2010. Research note: Effects of thymol and carvacrol feed supplementation on lipid oxidation in broiler meat. J. Poult. Sci. 89, 2, 366-370.
Matušovičová E., 1986. Technology of poultry industry (in Slovak). Príroda (nature) Bratislava.

Oser B.L., 1959. Protein and amino acid nutrition. Albanese Acad. Press New York, 281-291.

Pelicano E.R.L., Souza P.A., Souza H.B.A., Oba A., Norkus E.A., Kodawara L.M., Lima T.M.A., 2003. Effect of different probiotics on broiler carcass and meat quality. Braz. J. Poult. Sci. 5, 207-214.

Písaříková B., Kráčmar S., Herzig I., 2005. Amino acid contents and biological value of protein in various amaranth species. Czech J. Anim. Sci. 50, 169-174.

Sawar G., McDonough F.E., 1990. Review of protein quality evaluation methods. J. Assoc. Off. Anal. Chem. 73, 347-356.

Sherazi S.T.H., Talpur M.Y., Mahesar S.A., Kandhro A.A., Arain S., 2009. Main fatty acid classes in vegetable oils by SB-ATR-Fourier transform infrared (FTIR) spectroscopy. Talanta 80, 600-606.

Straková E., Jelínek P., Suchý P., Antonínová M., 2002. Spectrum of amino acids in muscles of hybrid broilers during prolonged feeding. Czech J. Anim. Sci. 47, 519-526.

Straková E., Suchý P., Herzig I., Steinhauser L., Šerman V., Mas N., 2009. Amino acid profile of protein from pelvic limb long bones of broiler chickens. Acta Vet. Brno 78, 571-577.

Sun D.W., 2009. Infrared spectroscopy for food quality analysis and control. Elsevier Acad. Press San Diego, USA.

Wattanachant S., Benjakul S., Ledward, D.A., 2004. Composition, color and texture of thai indigenous and broiler chicken muscles. Poult. Sci. 83, 123-128.

Accepted for print - Zaakceptowano do druku: 2.07.2014

Received - Przyjęto: 17.02.2014

For citation - Do cytowania

Alfaig E., Angelovičova M., Kral M., Bučko O., 2014. Effect of probiotics and thyme essential oil on the essential amino acid content of the broiler chicken meat. Acta Sci. Pol., Technol. Aliment. 13(4), 425-432. 